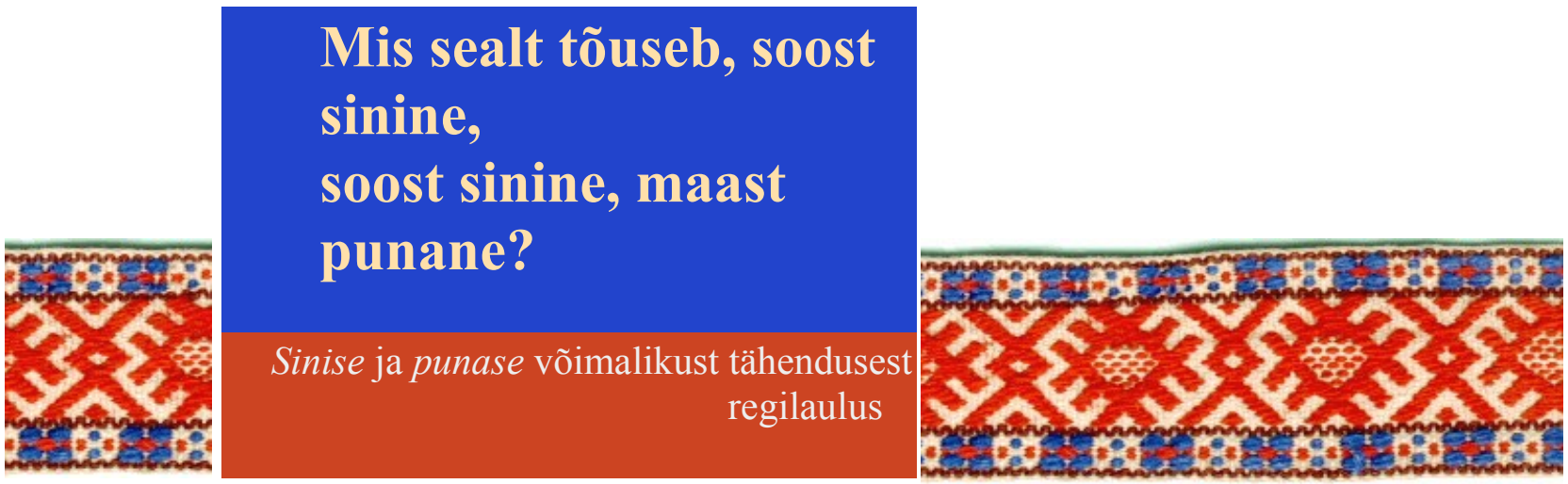

$\underline{\text { Tiiu Jaago }}$

Regilaulus kohtame tihtipeale värsirühmi, kus üksteisele järgnevad sinine ja punane, mõningail juhtudel lisandub neile järgmistes värssides kolmas värv või veel midagi. Seos värviga võib olla konkreetne ja visuaalne, märkides peksu jälge (kas seljas sinine märki/ või pales punane plekki,/ täppi täiessa lihassa *1); või viidata sakste riietusele (kui ne saksa santma lääva, /sinisärgi sitta vedama,/ punasärgi puid raguma,/ hahasärgi hakke vedama $*_{2}$ ). Tegemist võib aga olla abstraktse omaduse ülekandega, seda näiteks nõrga ja tugeva lauliku vastuseades (ole vaid sa, sinine,/ las mind laulda, ma punane $*_{3}$ ). Võrreldes usundilise taustaga loomismotiivides ja piirisituatsiooni (sünni-, kosja-, pulma- ja surma-) lauludes kasutatud sinise-punase parallelismiga on eespool toodud näited harvad või kitsa levikuga.

Regivärsilises mõistatuslaulus küsitakse - mis sealt tõuseb, soost sinine, soost sinine, maast punane? Mis saab olla ühel ja samal ajal nii sinine kui ka punane? Antud käsitluses otsime vastust küsimusele, millist tähendust võib omistada sõnapaarile sinine-punane regilaulu parallelismis.

\title{
Värvinimed regilaulus
}

Värvinimesid kasutatakse regilaulu kujundeis suhteliselt harva. Antoloogia "Eesti rahvalaulud" esimese köite esimese vihiku 772 laulust leidub värve 175 laulus ehk 22,6 \% tekstidest. Ometi ei iseloomusta need arvud kõiki tasandeid ja laule, sest värvinimede kasutamise rohkus sõltub veel lauluteemast: kosjafantaasias on see 46,5\%, mõistatuslauludes 42,3\%. Näiteks Haljala ja Helme pulmalauludest esineb värvisõnu vastavalt $36,4 \%$ ja $43 \%$ lauludest. $*_{4}$ Üldiselt ei ulatu värvikasutusega laulude arv ühe teema raames üle $47 \%$. Laulutüübiti võib see olla suurem: müütilise "Loomislaulu" tunnuslikud motiivid seostuvad enamasti sinise ja punasega, mistõttu 173 variandist sisaldab värvinimetusi 109 ehk $63 \% . \underline{* 5}$

Regilaulu värvivalik põhineb ühelt poolt keeles olevatel värvinimedel. Teiselt poolt sai laulik neid juurde luua keeleomase sõnamoodustamise loogikaga, identifitseerides värvi eseme kaudu. Juba viidatud regilaulu antoloogia 175 laulus kasutatakse 37 erinevat värvinimetust (v.a. kuld, hõbe, vask, mis võivad teatud kontekstis samuti olla värvinimed). Regilaulus esineb tänapäeva eesti keele 11 põhivärvinimest viis enamkasutatavat (must, valge, punane, sinine, hall) ning kaks haruldast (roheline ja kollane), seega kokku seitse. Sama kinnitavad regilaulu värvinimede statistilised vaatlused. 
Värvinimetuste loend ja esinemissagedus. Aluseks - Eesti rahvalaulud. An toloogia I:1, Tallinn 1969.

\begin{tabular}{|c|c|c|c|c|c|}
\hline Värvinimetus & esinemisarv & värvinimetus & esinemisarv & värvinimetus & esinemisarv \\
\hline 1. puna(ne) & 73 & $\begin{array}{l}\text { 14.- } \\
\text { 15.tahmakarva }\end{array}$ & 3 & 27. liedikarva & 1 \\
\hline 2.-4. sinine & 55 & $\begin{array}{l}\text { 14.-15. } \\
\text { tõrvaskand }\end{array}$ & 3 & $\begin{array}{l}28 . \\
\text { lepakarvaline }\end{array}$ & 1 \\
\hline 2.-4. hall & 55 & $\begin{array}{l}16 .-17 . \\
\text { veripunane }\end{array}$ & 2 & 29. urmatsed & 1 \\
\hline 2.-4. must & 55 & 16.-17. kollane & 2 & 30. heinakarva & 1 \\
\hline 5. valge & 44 & 18. paat & 1 & 31. sõmerakarva & 1 \\
\hline 6. kirju & 31 & 19. süsimust & 1 & 32. liivakarva & 1 \\
\hline 7. kõrb & 19 & 20. tõmmukarva & 1 & 33. päävakarva & 1 \\
\hline 8.-9. linakarva jne & 11 & 21. oravakarva & 1 & 34. murukarva & 1 \\
\hline 8.-9. ruuge & 11 & 22. lõhekarva & 1 & 35. pärjekirja & 1 \\
\hline 10. verev & 8 & 23. rauakarva & 1 & 36. taevakarva & 1 \\
\hline 11.-12. roheline & 5 & 24. piimakarva & 1 & 37. kannukarva & 1 \\
\hline $\begin{array}{l}\text { 11.-12. } \\
\text { rauarooste(karva) }\end{array}$ & 5 & 25. tulipunane & 1 & & \\
\hline 13. hiiehall & 4 & 26. verikõrb & 1 & & \\
\hline
\end{tabular}

Kui eeldada, et regilaul peegeldab siinses kontekstis keeleajalugu, siis on oo tuspärane, et regilaulu värvisõnastiku sagedustippu kuuluvad nimelt punane, must ja valge - vanimad põhivärvinimed. *7 Ootuspäraselt peaksid järgnema kollane ja roheline. Ometi on regilaulus need värvinimed haruldased, sest näiteks kollase asemel kasutati kuldset. (See selgitab ühtlasi eelpool toodud märkust värvinime kuld funktsioonist, ehkki pole selle sõna ainukeseks tähenduseks regilaulus). Roheline põhivärvinimena on suhteliselt noor, pärinedes 17. sajandist. *8 Sõnad (mitte mõisted) roheline, lilla ja eriti pruun ei ole regilaulu keelde oma nooruse tõttu kinnistunud või puuduvad sealt üldse. Üksikult esinevad roosa ja lilla on "külalised" uuemast laulu(kihi)st. $\underline{* 9}$

Kas me võiksime siit järeldada, et 19. sajandi regilaulude värvisõnastik peegeldab stereotüüpseid vormeleid, mis ku junesid välja enne 17. sajandit? Regilaulus sageli kasutatav sinine kuulub ju varasemasse perioodi, haruldane roheline kuulub 17. sajandisse, regi laulust puuduv pruun 18. sajandisse.

Päris nii lihtne see ei ole. Vaadelgem selguse mõttes probleeme, mis seostuvad sõnadega hall ja haljas. Viimast ei kohta me regilaulus mitte niivõrd värvinimetusena kui just selle sõna hilisemas tähenduses hiilgav, läikiv; taimede tärkamise ja puude rohelus . Järelikult, kui haljast ongi enne 17. sajandit regilaulus kasutatud põhivärvisõnana, siis on see seos regilaulust, nii nagu keelestki, taandunud. $\stackrel{* 10}{2}$ Teise küsimusteringi tekitab sõna hall. Regilaulus kohtame halli väga tihti kõrvuti 
punase, valge ja mustaga. Keeleajaloo-kontekstis see nii olla ei tohiks, sest hall põhivärvinimena on eesti keelde tulnud oletatavasti ühel ajal sõnaga pruun ehk 18. sajandil. *11 See sobiks ka Berlini ja Kay hüpoteesiga, kuigi eesti keele värvisõnade jälgimine seda üheselt ei kinnita. $\stackrel{* 12}{ }$ Võiks oletada, et hall regilaulus ei ole põhivärvinimi, vaid piirdub teatud objektide rühmaga. *13 Vaadates juhuslikkegi väljakirjutusi regilaulust, näeme, et hall märgib värvi nagu teisedki põhivärvinimed (alla musta mulla - võrdle - alla halli mulla *14; kellel halli manteli,/ kellel valge kasukas?/--/haaval halli manteli,/ kasel valge kasukas ${ }^{* 15}$ ). Sõnade hall ja haljas kasutus peegeldab eesti keele arengut 17 . sajandist 19 ndasse.

Kuigi regilaule loodi 19. sajandil, ja luuakse Setus praegugi, ei kohanenud selles kõik uued värvinimetused, sh üldkeeles nii tuntud sõnad nagu roheline ja eriti pruun. 16 Roheline on avastanud väga vähe alliteratsiooni võimalusi (ma laulan üle mereje/---/ rohelise Ruotsi vastu on suhteliselt saamatu kujund. *17) Seega ei peegelda sõnade roheline ja pruun pruukimine regilaulus eesti keele arengut läbi paari-kolme sajandi.

Regilaulukeel ei ole vahetult samastatav kaasaegse argikeelega. Laulu kujund luuakse regilaulule omastest stereotüüpsetest fraasidest, mis kujunesid välja teatud ajajärgul ja arenesid sellelt pinnalt edasi vastavalt oma otstarbe säilimisele või muutumisele. Värvinimesid must, valge, hall, punane ja sinine kasutatakse tihti ning mitmekesistes seostes. 17. sajandil tuntud ja hilisemadki põhivärvinimed kohanesid regilaulukeeles jõudsamalt, kui neil oli varasem kasutuspinnas (vrd hall). Uued sõnad jäid kujundilt algelisteks (roheline).

Värvisõnad regilaulus erinevad üksteisest esinemissageduselt ning kujundilise mitmeplaanilisuse poolest. Peamiselt 19. sajandil kogutud lauludes näeme esmapilgul vaid regilaulu ajatelje üht viimast tasandit. Jälgides värvisõnade kujunditausta, saavad nähtavaks ka teised tasandid. Mida sagedasem, väljaarenenum ja mitmekesisem on vaadeldav kujund, seda vanem ja tähenduslikum on see teiste kujundite seas.

\section{Värvinimed regilaulu kujundis}

Värvinimede kasutamine regilaulus allub selle üldiste ehitusvõtete loogikale. Regilaulu horisontaalseks teljeks on värsirida, vertikaalseks teljeks parallelism.

Regilaulu värsirida ei moodustu alati vabalt valitud sõnadest. Assotsiatsioone juhib sõna häälikuline koosseis - kõla. *18 Sõnad võivad olla kujunenud püsivaiks allitereeruvaiks sõnapaarideks $*_{19}$ Ühildumine võib toimuda mitte ainult sõna vaid ka silbi tasandil. Näiteks $p \ddot{a}$-silp tingib alliteratsiooni: kätte jäägu ohjaotsad,/ pähe päitsed punased; päev läks puudele (loodele) punane $\underline{* 20})$.

Nagu sõnad värsireas (horisontaalteljel) nii ka värsid parallel ismirühmas (vertikaalsel teljel) alluvad teatud reeglitele. Tavaliselt rõhutatakse parallelismi meeleolu loovat funktsiooni. $\underline{* 21}$ Parallelismi saab mõista kui mõtte sünonüümset või varieeritud kordamist:

Sinikirja linnukene,

sinikirja, siibakirja.

Loomine, ER1A $1<$ Haljala. 
Regilaulu parallelism on struktuurilt siiski mitmekesisem ja keerukam. Matti Kuusi uurimus muinasaja eepiliste laulude stiilikihtidest näitab mh parallelismi aste-astmelist kujunemist. Lihtsamates ja algsemates parallelismides kordab teine värss peavärsi mõtet (sinikirja linnukene - sinikirja, siiba kirja). Juba teise stiilikihi parallelism sisaldab korrelatiivsust: peavärssi mahub vaid osa informatsioonist, tekivad küsimus-vastus parallelismid, loet elu-parallelismid jne. $\stackrel{* 22}{22}$

Parallelismi esmaseks aluseks ei ole kunstikavatsuslikkus, vaid arhailise mõtlemise eripära - esitada üldine konkreetse kaudu. Seda loogikat kohtab rahvaluules üldisemaltki. 23 Disjunktiivsusest, mis selgitab näiliselt aloogilisi lauseid, kirjutas Jaan Kaplinski. $\underline{* 24}$

Tuli susi, suuri koera,

tuli karu, laia käppa,

laia käppa laanesta.

Kiskus minu kirju härja,

murdis minu musta härja,

ära sõi, sõge, mõlemad.

Härjad murtud, ER1 II Vi $2<$ Vaivara.

Laulunäites on härgi kaks ja mõlemad murti maha. Kes murdis härjad kui tulijaid on laulu sõnutsi kaks, murdjaid üks. Disjunktiivne loogika seletab meile, et pole tähtis, kas tuli hunt või karu. Tähtis on see, et tuli kiskja.

Disjunktiivsuse kõrval on teisigi võimalusi üldmõistete otsimiseks. Näiteks selliste konjuktiivsete värsside puhul nagu sinine, punane ja kuldne põõsas, või pilvel on hani punane, hanel on saba sini$n e$, pole loetelu detailid - paralleelsõnad - juhuslikud, vaid on täpselt ära määratud ning tähendavad koos midagi üldist. Värvinimedest on sellisteks paralleelsõnadeks näiteks must - valge; valge punane, *25 silmahakkavaimad on sinine ja punane. Seda nii oma kasutusseoste mitmekesisuse kui ka esinemissageduse poolest. Tavaliselt on sellistel paralleelselt esinevatel värvinimedel laulu semantikas keskne roll. Just siit saame teada millest on jutt. On ootuspärane, et värvid informatsiooni andjatena on värsis va bamad sõnade heakõla- ehk alliteratsiooniseostest. $\stackrel{* 26}{ }$ Vaatame näiteks pulmalauludesse kuuluvat veimede kiitust:

ilusad sinised lõngad,
ilusad punased lõngad,
valged lõngad on vahela,
kenad kirjad keske'ela.
E $16378(9)<$ Haljala.

Kahes esimeses värsis on muutuvaks (dünaamiliseks) osaks värvid, kusjuures muu osa kordub sõnasõnalt. Alliteratsioon puudub. Kolmas ja neljas värss ei korda enam eelmisi, vaid sõnastuses tehakse väike pööre: valged lõngad ja kenad kir jad on vahel, keskel. Need ei ole sama üldised kui sinised ja punased, need on teiste seas. Ühtlasi näeme, et viimastes, semantiliselt vähemtähenduslikes värsiridades toimib alliteratsiooniline sõnaseos (kenad - keskel; valged - vahel).

Punast, sinist ja valget värvi seostati pulmas kaitsefunktsiooniga, mis on vajalik piirisituatsiooni ületamiseks, ühest sotsiaalsest staatusest teise minekuks, mis toimetatakse siirderiituse kaudu. $\stackrel{* 27}{27}$ Näiliselt võivad sellised paralleelvärsid olla meeleolu süvendavad nagu eeltoodud näites. Ometi on 
kahe esimese värsi värvidel üldisem tähen-dus, see pole pelgalt konkreetne laulutekst. Kui pruut on vastuvõetav, siis on tema veimevakas ilusad sinised longad, / ilusad punased lõn-gad... Kui aga pruut ei meeldi, siis siga sõrgund sinista,/ hobu pursand punasta,/ koer on kusnud kol lavetta. *28 Samad värvid tähistavad vastupidist sõnumit. Värve ei saa selles kontekstis vabalt asendada, sest need osutavad pulma lauludes piirisituatsioonile.

Lähedase struktuuriga on järgnev palve:

Nüüd on lahti surmauksed, ahilata surma-auad.

Tule nüü, Marina, tubaje,

Püha Risti, põrmandalle,

leika sie sinine paela,

leika sie punane paela!

Nurganaine C. VK VI:2 1003

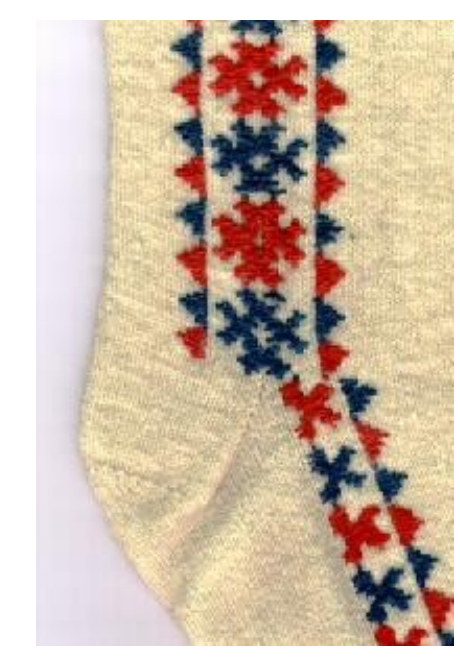

Laulus kajastub lapse sünni ootus. Haud on lahti naisele - sünnitajale. Sünd ja surm on üsna ühe koha peal. Tuppa tulnud Marina (Maarja) päästis valla sinise ja punase paela - laps sündis ning ühtlasi sulgusid surmauksed. Sinine ja punane seostuvad siin verega - elu ja surma, siin- ja sealpoolsuse märgiga. Sünni ja pulmade kohta käivaid väljendeid laiendatakse sageli ka surmale. *29 Sünd ja surm ei ole ainult bioloogiliseks, vaid ka kultuuriliseks piiriks, mida tuleb ületada siirderiituste abil. *30 Viimane näide on seega nii struktuurilt kui sisult eelmise - pulmalaulu veimede kiitmisega - sarnane. Mõlemas kuju tatakse üleminekuriitust.
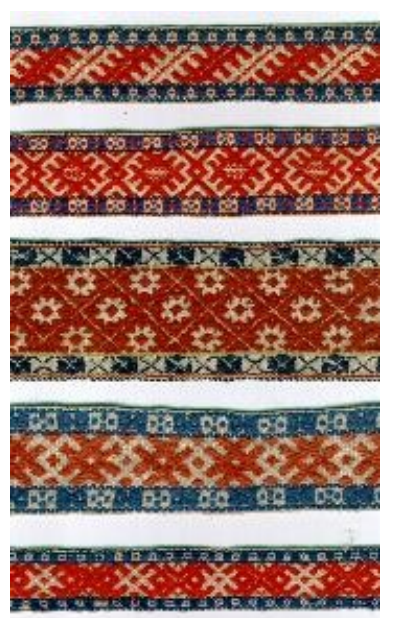

Eeltoodud näites täiendasid värvid üksteist paralleelvärssides, kuid neid võidi reastada ka nähtusi eristavaiks:
üks oli sinine põesas,
teine on punane põesas,
kolmas kullakarvaline.
Loomine. ER1A $1<$ Haljala.

Ka "Loomislaulu" lähemal vaatlemisel selgub, et sinise-punase-valge (kuldse) parallelismiseos ei ole juhuslik. Värve ei asendata või kui seda tehakse, siis viitab see kas traditsiooni lokaalsetele eri joontele või regilaulu uuematele kihtidele. $* 31$

Parallelismirühmades kasutatud sõnadele on rohkem või vähem omane see, et nad tähendavad koos olles midagi muud kui üksikult esinedes. $\stackrel{* 32}{2}$ Kindlasti ei ole sinine, punane ja valge või kuldne lihtsalt meeleolu väljendav luulepilt, mida võiks sõnastada teisiti, ilma et sisu muutuks. Kui võtta üks neist ära, ei ole enam sama tervikut. Teisisõnu: muna koosneb koorest, munavalgest ja rebust. Kui üks neist kolmest ära võtta, ei ole enam sama tervikut - muna. Pole juhuslik muna kujundi/objekti sagedane esinemine maailma loomismüütides. Selle parallelismiseose puhul saame rääkida loogikast, kus üksikosade loetelu - konkreetsus - annab üldmõiste, milleks on piirisituatsioon: piir siin- ja sealpoolsuse vahel, piir päeva ja öö vahel, piir sotsiaalsete staatuste vahel 
Mis alusel võis laulikul kujuneda sinise-punase-valge (kuldse) parallelism abstraktse piiri mõiste kujundlik-konkreetseks?

\section{Regilaulu värvikujund - tegelikkuse metafoor}

1980. aastate alguse ajakirjandust läbinud värviteema sai tõuke arvamusavaldustest rahvaluule värvimaailma kohta. *33 Mikk Sarv väitis, et punane seostub regilaulus elujõu ja tugevusega, sinine vastandub sellele nõrkuse ja haigusega. Samas on sinine ka kauguse ja hajuvuse värv. Sinine ja punane üheskoos seostub üleloomulike võimete ja jõuga. Sinine ja kollane koos tähistavad passiivsust, nõrkust ja surma. *34 Kahtlen selles, kas saame neid värve pidada sellisteks sümboliteks. Regilaulu puhul ei saa alati rääkida ühesest värvisümboolikast, sest sõnadel on poeetiline funktsioon ja need saavad oma ainulise tähenduse kontekstis. St kõik "punased" ei tähista täpselt ühte ja sama. Pean õigustatuks nende tähelepanekut, et värvid regilaulus üksikult tähendavad midagi muud, kui paralleevärssidesse koondatult.

1980. aastatel võrdles Mauno Koski oma värvinimede monograafias mh punase tähendusi karjala, soome, ingeri ja eesti regilauludes. Karjala lauludes seostub punane (mis ei ole seal põhivärvinimeks) sõnaga puri/ purjetama (punainen pursi; purjehti punaista merda. *35 Värss on levinud eesti lauludeski purjetan punasta merda. Taas näeme regilaulu omadust kujundada ja kasutada alliteratsioonilisi stereotüüpseid sõnapaare. Need ei ole mitte sümbolid, vaid kujundid, mis saavad kontekstis uusi tähendusi. Nende aluseks võib olla mingi ülekandeline aspekt, pärit ümbritsevast loodusest või usundilisest maailmapildist. Üheks regi lauluomaseks kujundimotiiviks on vihmapilv, millel on punane hani ja kellel omakorda on saba sinine (näiteks laulutüübid "Neli neidu", "Kulla põlemine", Lähme loojale loole", Pilves veepisarad").

Tõi tema pilved tullessa,

tõise pilve minnessaa.

Pilvel on puhas purje,

purjel on hani punane,

hanil on saba sinine,

saba peal on saksa sängi.

Pilves veepisarad. ERlA $427<$ Maarja-Magdaleena (1888).

Tooge pilved tullessa,

vikerkaari kaasassagi.

Pilves on veepisarad,

vikerkaares purjed suured.

Purjes on hani punane,

hane saba on sinine,

saba peal on saksa sängi.

Kulla põlemine. H II 10, 34 (25) < Kadrina (1889).

Motiiv on tuntud üle maa ja ei seostu niivõrd kindla laulutüübiga, vaid märkimisväärse hulga kosjamotiividega. Mauno Koski seostab sinise-punase parallelismi vikerkaarega. *36 
Kas sinise-punase parallelism regilaulu kujundis märgib vikerkaart?

Vikerkaart on muuhulgas peetud kahe maailma - siin- ja sealpoolsuse ühenduseks. Virve Sarapik järeldas vikerkaare usundi lis-mütoloogilistest kujutelmadest, et rahvausundis domineerib vikerkaare kuju - kaar, köis, ammukaar, sild, vöö. Üllatavalt vähe mainitakse vikerkaarega seoses värve, kusjuures tänapäevast kujutlust vikerkaare seitsmest värvist ei kohta me kusagil. Samas viidatakse eesti rahvaluule teistes liikides - mõistatustes ja lauludes - vikerkaare sinisele ja pu nasele värvile. V. Sarapik kahtles, kas regilaulus nii levinud sõnaparallelismi nagu seda on sinine-punane võib mõista siiski vikerkaarena, kuigi näiteid selle tõestuseks leidub. $* 37$

Võib nõustuda Virve Sarapiku väitega, et ei saa absolutiseerida sinise ja punase parallelismi seotust vikerkaare kujutamisega regilaulus, kuigi vikerkaar on selles kujutelmadereas olemas. Üldisem mõiste (ka vikerkaarest) on ikkagi piir. Vikerkaare motiivi erijooned, võrreldes teiste analoogsete sinise ja punase parallelismidega on esmalt alliteratsioonilise sõnapaari puri - punane olemasolu ning asjaolu, et puudub kolmas värv; ja see, et värvisõnade reastuses on eelistatud peavärsis järjekorda punane, parallelvärsis sinine, mitte vastupidi.

Vikerkaare kujutamine kahe värvi abil kõneleb regilaulu parallelismi loogikast: siin saab asendada üldmõistet (vikerkaar) selle osade nimetamise kaudu. Ja nendeks osadeks, mis hõlmab loendina kogu tervikmõistet võivad olla värvid: sinine ja punane poolus tervikvärvireas.

Looduse ja taevakaarega (silmapiiriga) seondub sinise-punase parallelism ka martide teekonnakirjelduses, kus mart on tulnud kaugelt:

ümber see ilma ümara,

kaugelt see kuu kumera,

päält see päiva punase,

tagant taevaje sinise.

RKM I 20, 258 (2) < Paistu (1915).

Sellele motiivile on iseloomulik esmalt alliteratsiooniline sõnapaar päev-punane ning taas gradatsiooni alustamine parallelismi tugevamast liikmest - punasest. Näiliselt nii poeetiline looduspilt ei ammendu sõnumiga ilusast looduspildist. Tekst ise vihjab sealpoolsusele. Kui mardi- ja kadrilaulude teekonnakirjeldusi sihipäraselt jälgida, on nende tekstide usundiline taust ilmne. Mardilaulude teekonnakirjeldustes on Ülo Valgu uurijasõelale jäänud kuld-hõbe-vask parallelism kui märk ebamaisest teekonnast. *38 Teistes lauludes, tõdeme koos Ülo Valguga, on ühes ja samas funktsioonis kasutatud erinevaid sõnastusi, näiteks ka sinise-punase parallelismi vaeslapselaulus, kus orb pöördub kadunud ema poole sõnadega:

Minu hella eidekene, siruta sinine longa, poeta punane longa, keera kullakarmeline, tõmma tütar taeva_aie /---/. Tõmba tütar taevasse. ER1A $3394<$ Haljala (1891). 
Kolme värvi tüüpilise parallelismi gradatsioon algab sinisest ja lõpeb kullaga. Samasugune värviparallelism on iseloomulik "Loomislaulule":
Lind, kirju linnukene, lendas meie kopli peale. Meie koplis kolme põesast: üks oli puu sinine põesas, teine puu punane põesas, kolmas kullakarvaline. Põlgas see sinise põesa, põlgas see punase põesa, hakkas kulda armastama. Erl I Vi $21<$ Kadrina.

\begin{abstract}
"Loomislaulu" sinise-punase-kuldse parallelismis on enamik uuri jaid seadnud esiplaanile poeetilisuse. Loomislaulu muutumisest naiselikuks lüürikaks räägib Onni Okkonen. *39 Kaarle Krohn kirjutab regilaulu värvilistest põõsastest kui looduskujundist: On ollut auringonlaskun aika, jolloin punainen, sininen ja keltainen väri on vaihdellut sekä taivalla että heijastuksena maan pinnalla. *40 Eelöeldut seostatakse neidude unistuste ja luulendustega kiigel. Müütilisuse kadumisest ja loodusluulendusest 19. sajandil kogutud "Loomislauludes" kõneleb ka Ingrid Rüütel. *41
\end{abstract}

Teisiti lähenevad probleemile Mikk ja Tõnn Sarv. Nemad seletavad kolme värvi tähendust muutumise ja paigalseisu vaheldumisena. "Loomislaulu linnukene põlgas ära sinise ja punase põõsa," loeme Mikk ja Tõnn Sarve kirjutisest. "Ta hakkas armastama kuldset põõsast - päikese, pöörase venna, liikumise ja muutumise võrdkuju." $\underline{* 42}$

Tõdegem koos kõigi autoritega, et "Loomislaul" on palju muutunud ja 19. sajandi repertuaaris on tal tugev lüürilis-meeleoluline koloriit, kuid selle peidust on võimalik näha müütilise ja usundilise tasandi piirjooni.

"Loomislaulu", pulmalaulude, ka vaeslapselaulude tunnuslikeks erijoonteks on rõhuasetuse puudumine alliteratsioonilistele sõnapaaridele; paralleelsõnadest värvinimed tulevad värsis esile ja annavad tekstile üldisema (usundilise) tausta; gradatsioon parallelismirühmas algab parallelismi nõrgemast liikmest - sinisest; lauldakse kolmest värvist - sinisest, punasest ning kuldsest.

Sinise-punase parallelismi üheks allikaks on looduselamused, kusjuures sellele on omistatud usundiline tõlgendus. Vikerkaar, silmapiir, päikeseloojang (piir päeva ja öö vahel) - need nähtused on ühelt poolt visuaalselt tajutavad ja seostuvad värvielamustega. Teisalt on need elamused ka sakraalse maailma peegelduseks, sõnumiks teispoolsusest. *43 Neid kujutelmid on nii looduses kui ka usundilises maailmapildis seostatud piiri mõistega. Sinise-punase parallelism seondub piiriga

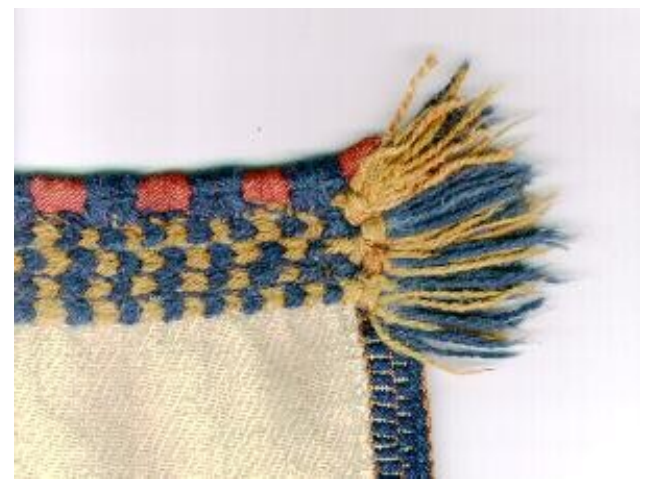


looduses ning ka pöördemomentidega inimese elus. Punase ja sinise värvipaari (mitte üksikult esineva värvi!) ulatuslikust sümboolikast eri kultuurides on kirjutanud Leopold Schmidt. Tema arvates saab värvipaari ja sageli sellele lisanduva kolmanda värvi sümboolikast rääkida seoses mitmete Euroopa riikide lipuvärvidega; alates 15. sajandist on näiteid Euroopa rõivamoest, mille abil eristatakse mehi ja naisi, poisse ja tüdrukuid. Autor jõuab kahe olulise aluspõhjani selle nähtuse kirjeldamisel. Esiteks selleni, et tähenduslik mõju on nimelt värvipaaril (-grupil), mitte üksikul värvil. *44 Teiseks selleni, et sinise-punase kasutamisel pulmakombestikus (näiteid üle Euroopa) on juured kaugel minevikus (autor esitab näiteid lisaks Euroopa kultuuridele Vanast Indiast). Sellel värvipaaril on sümboolne imejõud (kaitsefunktsioon) ning naist ja meest kui kaht erinevat, ent ometi inimesena kokkukuuluvat tegelast eristav funktsioon. $\underline{* 45}$ See tasand on metafoorsem looduspiiri märkivast tasandist.

Laulu aluseks on loodus ja materiaalne maailm tervikuna. Kuid sealhulgas on tähtis, kuidas kultuuris tõlgendatakse ümbrust. Maailmanägemused ja tähenduste ülekanded (näiteks vereohvri asendamine punase $* 46$ lõngaga) kuuluvad kultuuri valda. Tähelepanuväärne on veel üks seik: näited kipuvad olema pärit Põhja-Eestist. Aga ega ometi ainult seal olnud taevas ja maa päikeseloojangul täis sinist, punast ja kuldset valgust! Tõesti mitte. Näidete koondumist Põhja-Eesti lauludesse ei ole kindlasti juhuslik. Just sealsele traditsioonile on iseloomulik järjekindel sinisepunase parallelism, mis tugineb Põhja-Eesti regilaulude tunnuslikule eripärale hoida alal varem lauldut, vastukaaluks Lõuna-Eesti improvisatsioonilisusele. $* 47$

Värvisõnade kasutamine selliste kujutelmade sõnastamisel on ootuspärane kolmel põhjusel. Need on sellistena nähtavad-tajutavad reaalilmas. Teiselt poolt on regilaulu keelele omane üldmõistete moo dustamine konkreetse - nähtuste osade - loetlemise kaudu. Kolmandaks - nii olid sõnastanud oma laulud selle maanurga laulikud juba enne meid. Loodus, usund, elamus, kujund - sellepärast on piir regilaulus sinine ja punane ühel ja samal ajal.

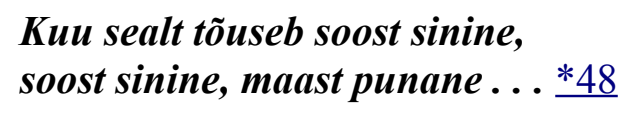

\section{Kasutatud allikad}

\section{Käsikirjad}

Eesti Rahvaluule Arhiivi rahvalulude käsikirjaline kogu $(\mathrm{H}=$ Hurt; $\mathrm{E}=$ Eisen; $\mathrm{RKM}=$ Riiklik Kirjandusmuuseum; tüpoloogiliselt korraldatud regilaulu koopiate mapp nr. 73).

Jaago, Tiiu. Loengud regilaulu värvidest. Käsikiri autori valduses.

Jaago, Tiiu. Loengud "Rahvalaul I". Käsikiri autori valduses.

Roll, Tiiu. Epiteet eesti regivärsilises rahvalaulus. Väitekiri filoloogiateaduste kandidaadikraadi taotlemiseks, Tartu 1990. Käsikiri TÜ Teadusraamatukogus. 
Trükised

Allik, Jüri. Värvitaju, värvinimetused ja värvisümboolika. Looming, nr 3, 1982, 378-384.

ER1 = Eesti rahvalulud. I-II. Tartu 1926-1932.

ERIA = Eesti rahvalaulud. Antoloogia I:IV. Tallinn 1969-1974.

Eliade, Mircea. Sakraalne ja profaanne. Vikerkaar, nr 4-12, 1992. (M. Eliade. The Sacred \& the

Profane. The Nature of Religion, 3. tr. San Diego, New York, London 1987).

Hattenhauer, Hans. Euroopa õiguse ajalugu I. Tartu 1995.

Järs, Anu. Selge meele ja targa mõistusega. Pro Ethnologia. 3, Tartu 1995, 122-131.

Kaplinski, Jaan. Parallelismist lingvisti pilguga. Keel ja Kirjandus, nr 3, 1972, 132-145.

Kolk, Udo. Värsisisesed vormelid eesti regivärsilises rahvalaulus. TRÜ Toim. 117. Tartu 1962, 71152.

Koski, Mauno. Värien nimitykset suomessa ja lähisukukielissä. Savonlinna 1983.

Krohn, Kaarle. Kalevalankysymyksiä. II, Helsinki 1918

Kuusi, Matti. Kalevalaisen muinasepiikan viisi tyylikautta. Kalevalaseuran vuosikirja 37. Porvoo 1957,109-128.

Laugaste, Eduard. Eesti regivärsi struktuuri küsimusi. TRÜ Toim. 117. Tartu 1962,25-70.

Laugaste, Eduard. Eesti rahvaluuleteaduse ajalugu. I. Tallinn 1963.

Laugaste, Eduard. Sõnaalguline ja sisealliteratsioon eesti rahvalauludes. TRÜ Toim. 234. Tartu 1969, 3-356.

Okkonen, Onni. Maailmansynty-runo. Kalevalaseuran vuosikirja. 1, 1921, 123-137.

Parmasto, Erast. Mitmevärviline maailm. Looming, nr 3, 1982, 375-377.

Richter, Elisabeth. Mõningaid arhailisi jooni Setu matusekommetes. Läänemeresoomlaste etnokultuurilisi küsimusi. Tallinn 1982, 96-100.

Roll, Tiiu. Värvinimetused ja nende kujundiline osa regivärsilises pulmalaulus. TRÜ Toim. 699. Tartu 1985, 34-58.

Roll, Tiiu. Regilaulu epiteedi analüüsi võimalusi. TÜ Toim. 943. Tartu 1992, 61-65.

Rätsep, Huno. Läänemeresoome värvimaailm. /Retsensioon Mauno Koski monograafiale Värien nimitykset\&ldots;/. Keel ja Kirjandus, nr 1, 1985, 58-59.

Rüütel, Ingrid. Muistne "Loomislaul" eesti uuemas rahvatraditsioonis. Paar sammukest eesti

kirjanduse uurimise teed. VI. Tallinn 1969, 102-132.

Rüütel, Ingrid. Kihnu pulmakombed - juured ja suundumused. Rahvausund tänapäeval. Tartu 1995, 328-354.

Sarapik, Virve. Vikerkaar, värv ja teadusmütoloogia. Eksperimentaalne foloristika. Tartu 1993, 4959.

Sarapik, Virve.Valge ja must. Pro Foloristica II. Loomine. Tartu 1994, 37-46.

Sarapik, Virve. Valge ja must. Keel ja Kirjandus, nr 11, 1994, 641-649.

Sarv, Mikk \& Tõnn. Loomise lugu. Eesti Loodus, nr 7, 1979, 449-452.

Schmidt, Leopold. Volksglaube und Volksbrauch. Berlin 1966.

Sutrop, Urmas. Eesti keele põhivärvinimed. Keel ja Kirjandus, nr 12, 1995, 797-808.

Sutrop, Urmas. Värvisõnad: ääremärkusi Taani hindamisraamatu Eestimaa lehtede kohta. Keel ja

Kirjandus, nr 4, 1996, 225-229.

Sutrop, Urmas. Eesti keele värvussõnavara arengu põhijooni. Keel ja Kirjandus, 10, 1996, 661-674.

Valk, Ülo. Eesti mardilaulude usundilisest taustast. Rahvausund tänapäeval. Tartu 1995, 471-478.

VK = Vana Kannel. VI:1 ja 2, Haljala. Tallinn 1989.

Viires, Ants. Eestlaste värvimaailmast. Keel ja Kirjandus, nr 6, 1983, 290-302.

Värvid, arvud, kujundid esivanemate maailmapildis. Looming, nr 11, 1981, 1600-1608.

Weber-Kellermann, Ingeborg. Landleben im 19. Jahrhundert. 2., täiend. tr. München 1988. 


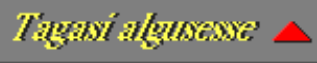

\section{Kommentaarid ja viited}

1 ERIA $6446<$ Haljala.

2 ER1A $2759<$ Otepää.

3 ER1A $335<$ Mustjala.

4 Tiiu Roll. Värvinimetused ja nende kujundiline osa regivärsilises pulmalaulus. TRÜ Toim. 699. Tartu 1985, 34-58.

5 KM ERA tüpoloogiliselt korraldatud regilaulude koopiate mapp nr.73; Tiiu Jaago, Loengud regilaulu värvidest. Käsikiri autori valduses.

6 KM ERA tüpoloogiliselt korraldatud regilaulude koopiate mapp nr.73; Tiiu Jaago, Loengud regilaulu värvidest. Käsikiri autori valduses.

7 Urmas Sutrop. Eesti keele värvussõnavara arengu põhijooni. Keel ja Kirjandus, nr 10, 1996, 661674.

8 17. sajandil hakkas seni rohelist värvi märkiv sõna haljas taanduma uue sõna - roheline - ees (Urmas Sutrop. Värvisõnad: ääremärkusi Taani hindamisraamatu Eestimaa lehtede kohta. 226. Keel ja Kirjandus, nr 4, 1996, 225-229).

9 Näiteks Eesti rahvalaulude antoloogia 772 laulu 37 erineva värvinime seas lillat ja roosat ei ole.

10 Näiteks Eesti rahvalaulude antoloogia 772 laulus esineb haljas kümnes laulus: haljas on -heiv-: mõõk (ERIA 7; 168), hagu (ER1A 21, 768) ja hõbe (487); ja lehtes puud: kask ja haab või tärkav oras (ERIA 474, 486, 495; 460, 461). Parallelsõnadeks on metallid (kuld, hõbe) või läikiv kard, aga mitte värvid.

11 Urmas Sutrop. Eesti keele värvussõnavara arengu põhijooni, .670. Keel ja Kirjandus, nr 10, 1996, 661-674.

12 Huno Rätsep. Läänemeresoome värvimaailm, 58 Keel ja Kirjandus, nr 1, 1985, 58-59.

13 Värvinimed tulevad keelde reeglina seda värvi objekti kaudu. Põhivärvinimi saab olla siiski üldisem mõiste, mille kasutusala ei ole piiratud teatud objektidega (Urmas Sutrop. Eesti keele põhivärvinimed. Keel ja Kirjandus, nr 12, 1995, 797-808). 
Nii halli kui ka teiste eesti keele värvinimede kujunemisel peab Ants Viires. (Eestlaste värvimaailmast, $291 \mathrm{jj}$ Keel ja Kirjandus, nr 6, 1983, 290-302) üheks oluliseks teguriks loomade eristamist värvi järgi. Seda väidet toetab hall, mis märgib kõigis eesti murretes halli hobust. Hall kujunes põhivärvinimeks Põhja-Eesti murrete mõjul. Stahli gram matikas 1637.a. on hall esitatud värvinimena, siis Gutslaffi lõunaeesti grammatikas 1648. a. on samas positsioonis hahk-sõna, hall seondub siin piiratud mõisterühmaga - hallid juuksed (Mauno Koski. Värien nimityk set suomessa ja lähisukukielissä. Savonlinna 1983, 175).

Ants Viirese seisukohta värvinimede päritolu ühest olulisest tegurist toetab ka punase kasutuselevõtt kolmtuhat aastat tagasi vereva asemel, mis taas seostub looma karva värvusega. "Et sõna -puna /---/ tähendus oli varem "karv", siis on küllalt tõenäoline, et asendus verev - punane nihutas mõiste punane fokaalpunkti pruunika (hallika) spektriosa poole. Võrdluseks võib tuua eesti punast tõugu karja, punased lehmad, kes tegelikult on ju punakaspruunid." (Urmas Sutrop. Eesti keele värvussõnavara arengu põhijooni. 667. Keel ja Kir jandus, nr 10, 1996, 661-674.)

14 Näiteks ERlA $69<$ Koeru ja ERlA $119<$ Jõhvi.

15 ER1A $759<$ Hanila.

16 ER1A laulutüüp 1351. Kust saks saapad saanud - ühes varian dis (laul nr 2796) on värsid: Kust sai kubjas kune selga,/ aidamees sai halli vati, /kilter Peeter kirju vesti /---mõisaproua pruuni kleidi - / kui põleks vaemud vaeva näinud,/ teopoisid tööda teinud! < Jüri. See on seni ainus regilaulunäide, kus ma olen kohanud sõna pruun. Teistes selle tüübi variantides sama sõnastust ei ole. Laul on üles kirjutatud 1891.a. Näeme, et sõna pruun oli keeles olemas, kuid regilauluomaseks see ei kujunenud.

17 ER1A $241<$ Kuusalu. Kolm statistikatabelis näidatud rohelise kasutust pärinevad sellest laulust ja seostuvad sõnaga Rootsi; ülejäänud kaks rohelise kasutust on seotud sõnaga roosiline (Soitsin teeda tippilista,/ rohelista, roosilista,/ maada marjavarsilista - ER1A $78<$ Kuusalu). Mõlemad seosed on võimendatult alliteratsiooni lised ja kujundiliselt üheplaanilised, mis kõneleb selle kujundi arengu al gusest ja viimistlematusest (vt. lähemalt regilaulu kujundi arengu skeemi: Ju han Peegel, Riivamisi regivärsist. Keel ja Kirjandus, nr 6, 1991, 321-333).

18 Eduard Laugaste statistiline uurimus regilaulu algriimist näitab, et allitereeruvate sõnade arv jääb 70-77\% vahele. - Eduard Laugaste. Sõnaalguline ja sisealliteratsioon eesti rahvalauludes, .93. TR $\ddot{U}$ Toim. 234. Tartu 1969, 3-356.

19 Eduard Laugaste. Eesti regivärsi struktuuri küsimusi, .27. TRÜ Toim. 117. Tartu 1962, 25-70; Udo Kolk. Värsisisesed vormelid eesti regivärsilises rahvalaulus, .76 jj TRÜ Toim. 117. Tartu 1962, $71-152$.

20 Tiiu Roll. Epiteet eesti regivärsilises rahvalaulus. Väitekiri filoloogiateaduste kandidaadikraadi taotlemiseks. Tartu 1990, 150-152. Käsikiri Tartu Ülikooli Teadusraamatukogus.

21 Eduard Laugaste. Eesti regivärsi struktuuri küsimusi, 32-50. TRÜ Toim. 117. Tartu 1962, 25-70.

22 Matti Kuusi. Kalevalaisen muinasepiikan viisi tyylikautta. Kalevalaseuran vuosikirja. 37. Porvoo 1957, 109-128. 
23 Vt näiteks Hans Hattenhauer. Euroopa õiguse ajalugu I. Tartu 1995, 27-33; Anu Järs, Selge meele ja targa mõistusega. Pro Ethnologia 3. Tartu 1995, 122-131.

24 Jaan Kaplinski. Parallelismist lingvisti pilguga, 135-136. Keel ja Kirjandus, nr 3, 1972, 132-145.

25 Tiiu Roll. Värvinimetused ja nende kujundiline osa. TRÜ Toim.699. Tartu 1985, 34-58.

26 Tiiu Roll. Regilaulu epiteedi analüüsi võimalusi. TÜ Toim. 943. Tartu 1992, 61-65.

27 Vt näiteks Ingrid Rüütel. Kihnu pulmakombed - juured ja suundumused, 331-334. Rahvausund tänapäeval. Tartu 1995, 328-354; Leopold Schmidt. Volksglaube und Volksbrauch. Berlin 1966, 94-95; Tiiu Roll. Värvinimetused ja nende kujundiline osa ... TRÜ Toim. 699. Tartu 1985, 34-58.

28 H II 9, 211 (9) < Haljala ja EÜS XI 838 (42) < Haljala. Vt ka Vana Kannel VI:2: 906. Tänu veimede eest; 908. Veimede kiitmine ; 909. Kas need mõned annid!; Tiiu Roll. Värvinimetused ja nende kujundiline osa ..., 44-45. TRÜ Toim. 699. Tartu 1985, 34-58.

\section{Leopold Schmidt. Volksglaube und Volksbrauch. Berlin 1966, 95-96.}

30 Mõned näited sinise ja punase metafoorsest kasutusseosest tavan dis. Johann Arnold von Brand (1647-1691) kirjeldab Lõuna-Eesti matusekom mete osa, kus sinised ja punased lõngad seotakse puu külge. (Eduard Laugaste. Eesti rahvaluuleteaduse ajalugu I. Tallinn 1963, 78.)

"Punane lõng, mis seoti matuste ajal puuokstele, oli kadunu auks ohver datud looma sümboliks. Selle kombetalituse algeid tuleb otsida ida poolt, val gasoomlaste, konkreetsemalt maride juures, kellel taoline ohvrirituaal säilis eriti kaua. /---/ Püüe asendada laostavad vereohvrid sümboolse ohvriga tärkas maridel alles 19. sajandi lõpul ja 20. sajandi algul." (Elisabeth Richter. Mõningaid arhailisi jooni Setu matusekommetes. Läänemeresoomlaste etnokultuuri küsimusi. Tallinn 1982, 96100.)

"Uig on valge, eest punasest ja sinisest lindist sikk-sakk-kaunistusega kõrge, koonusekujuliselt pähe asetatud valge rätt, mille all oli tavakohaselt väike valge tanu ja selle peal valge tikitud linik. Selline maagiline kol marv pidi veelgi tugevdama kaitset kurja silma ja nõiduse vastu./---/ Ornamentikas ja kogu nooriku rõivastuses domineerib punane värv, mida Kihnus peetakse nooruse ja rõõmu värviks. Punasetriibulist nn. punast körti kannavad praegugi tüdrukud ja noored naised ka argipäeval, vanemad naised aga üksnes pidulikel juhtudel. Isegi siis, kui peres on lein ja naine kannab musta leinakörti, peab ta pulma minnes panema selga nn sinise seeliku, milles on ka natuke punast, muidu võivat noorikule midagi halba juhtuda. /---/ Pruut pani poolpunase /ühe-kahe laia sinise triibuga seelik, mida kannavad keskealised naised/ kördi esmakordselt selga esimesel pulmapäeval kodust lahkudes või kirikusse laulatusele minnes, mis võis toimuda juba enne pulmi. Noorikuks ehtimisel vahetas ta selle pu nase kördi vastu, mis kuulub noorikutanu juurde. Halba vältida ja tõrjuda püüdva kaitse-, tõrje- ja ennetusmaagiaga seotud kombed ja laulud on nüüd lõppenud." (Ingrid Rüütel. Kihnu pulmakombed - juured ja suundumused, 333-334; 340-341. Rahvausund tänapäeval. Tartu 1995, 328-354).

Pruudi riietuse värvidest, eriti sinise ja punase värvi osast selles vt ka Ingeborg Weber-Kellermann. Landleben im 19. Jahrhundert. 2., täiend. tr. München 1988, 66; Leopold Schmidt. Volksglaube und Volks brauche. Berlin 1966, 94.

31 Ingrid Rüütel. Muistne "Loomislaul" eesti uuemas rahvatraditsioonis. Paar sammukest eesti kirjanduse uurimise teed. VI. Tallinn 1969, 102-132; Tiiu Roll. Epiteet eesti regivärsilises 
rahvalaulus. Väitekiri filoloogiateaduste kandidaadikraadi taotlemiseks. Tartu 1990, 131-140. Käsikiri Tartu Ülikooli Teadusraamatukogus.

32 Näiteks kui saan alla musta mulla,/valge laudade vahele; võib esineda ka teises sõnastuses: kui saan alla halli mulla, / valge laudade vahele. Värsirida võib allitereeruvaid sõnapaare muuta (musta mulla; alla halli). Kõnesolev sinise-punase ühendus on lahutamatu; värsirea tasand on nõrgem ja see parallelismi ei muuda.

33 Mikk Sarv \& Tõnn Sarv. Loomise lugu. Eesti Loodus, nr 7, 1979, 449-452; Värvid, arvud, kujundid. Esivanemate maailmapildist. Looming, nr 11, 1981, 1600-1608; Erast Parmasto.

Mitmevärviline maailm. Looming, nr 3, 1982, 375-377; Jüri Allik. Värvitaju, värvinimetused ja värvisümboolika. Looming, nr 3, 1982, 378-384.

34 Värvid, arvud, kujundid. Esivanemate maailmapildist, 1601-1602. Looming, nr 11, 1981, 16001608.

35 Karjala laulus võib punane ja sellega seonduvad motiivid olla arhaismid või fennismid ( Mauno Koski. Värien nimitykset suomessa ja lähisukukielissä.70-71. Savonlinna 1983, 64-97).

36 Mauno Koski. Värien nimitykset suomessa ja lähisukukielissä.72. Savonlinna 1983, 64-97.

37 Virve Sarapik. Vikerkaar, värv ja teadusmütoloogia. Eksperimentaalne foloristika. Tartu 1993, 54-55.

38 Ülo Valk. Eesti mardilaulude usundilisest taustast. Rahvausund tänapäeval. Tartu 1995, 471478.

39 Onni Okkonen. Maailmansynty-runo. 133-134. Kalevalaseuran vuosikirja. 1, 1921, 123-137.

40 Kaarle Krohn. Kalevalankysymyksiä II. Helsinki 1918, 19-20.

41 Ingrid Rüütel. Muistne "Loomislaul" eesti uuemas rah vatraditsioonis. Paar sammukest eesti irjanduse uurimise teed VI. Tallinn 1969, 102-132.

42 Mikk ja Tõnn Sarv. Loomise lugu. 452. Eesti Loodus, nr 7, 1979, 449-452.

43 Vt lähemalt Mircea Eliade. Sakraalne ja profaanne. Vikerkaar, nr 4-12, 1992.

44 Võrdle esitatut Jüri Alliku seisukohaga: Allik eraldab iseseisvate nähtustena värvitaju värvide nimetamise ja värvisümboolika. Värvisümboolikat kasutatakse palju, kuid selle universaalsus ei seisne kindla värvi ja vastava nähtuse kokkuvii mises (põhimõttel: sinine tähendab avarust), vaid põhimõttes: kui üht vastandlikest nähtustest väljendatakse ühe värvi abil, siis teist teise värvi abil. See teebki värvisümboolikas oluliseks värvipaari (Jüri Allik. Värvitaju, värvinimetused ja värvisümboolika, 384. Looming, nr 3, 1982, 378-384).

45 Leopold Schmidt. Volksglaube und Volksbrauch. Berlin 1966, 89-99.

46 Siinjuures on märkimisväärne, et üks punast märkivaid põhivärvinimesid verev on tuletatud 
verest ja et Lõuna-Eesti murretes see jäigi põhivärvinimeks (Urmas Sutrop, Eesti keele värvussõnavara arengu põhijooni. Keel ja Kirjandus, nr 10, 1996, 661-674).

47 Tiiu Jaago loengud Rahvalaul I. Käsikiri autori valduses.

48 ER1A 747 Mõistatuslaul < Kadrina. Kuid tõusta, soost si nine, soost sinine, maast punane võib ka päev - ER1A $751<$ Ambla.

Ka regilaulu meetrilise pildi teisenemine võib muuta värvisõnade kasutust laulus (sini- asemel siidipuhttrohheilise värsimõõdu puhul), kuid hetkel jääb see vaateväljast kõrvale. 